\title{
Инсценирующая диктатура. 90 лет Шахтинскому процессу 1928 г.
}

С.А. КРАСИЛЬНИКОВ, доктор Исторических наук, Институт ИсториИ СО РАН, Новосибирский государственный университет, Новосибирск.

E-mail: krass49@gmail.com

В статье предпринято переосмысление причин, целей, средств и результатов организации и проведения одного из крупнейших советских судебных политических процессов (Шахтинский, 1928 г.). Обосновывается, что процесс, по форме направленный против «спецов-вредителей», был в реальности ответом, способом выхода партийного государства из глубокого системного кризиса (падение его легитимности, рост негативизма рабочих к институтам власти, разрастание социальной напряженности). Положив в основу показательного суда модель и технологии конфликтной мобилизации («мы - они»), сталинское руководство не только пожертвовало интересами и статусом специалистов, но и прагматично использовало ресурс недовольства самих рабочих «отложенной» реализацией продекларированных для них льгот и преференций. Доказывается, что, перенацеливая протестный активизм рабочих в безопасное для себя русло «спецеедства» и поощряя настроения социального реванша «низов» в отношении интеллигенции, власть тем самым порождала и углубляла новые кризисные ситуации (деформация социально-трудовых отношений, расширение действия административных и репрессивных практик в сферах управления и экономики).

Ключевые слова: кризис легитимности власти, рабочий протест, социальная мобилизация, Шахтинский судебный процесс, «кампанейское правосудие»

В течение почти полутора месяцев (18 мая - 6 июля 1928 г.) Колонный зал Дома союзов, традиционно использовавшийся советской властью для проведения официальных и праздничных мероприятий в абсолютно позитивном контексте, оказался оперативно перепрофилирован для совершенно иного действия. Здесь разворачивался один из самых знаковых открытых судебных политических процессов раннесоветской эпохи: судили «организаторов» и «исполнителей» «экономической контрреволюции в Донбассе». Все обвиняемые (53 чел., в том числе трое немецких подданных) по своей производственной и управленческой деятельности были связаны с трестом «Донуголь», в который входили предприятия Северо-Кавказского края и Украины. Тем не менее судебный процесс стал именоваться «Шахтинским»по названию города Шахты, где местные, а затем прибывшие 
им в подкрепление ростовские чекисты и «обнаружили» первые «вредительские организации» технической интеллигенции. «Вредителям» инкриминировали акты саботажа, связи с находившимися в эмиграции бывшими хозяевами угольных шахт и другие «контрреволюционные деяния». По целям и уровню мощнейшей идеолого-пропагандистской кампании, охватившей разные слои и группы общества, к данному процессу вполне применим термин, введенный в научный оборот немецким историком Мальте Рольфом [Рольф, 2009. С. 7], изучавшим природу и формы развития массовых советских праздников - «инсценирующая диктатура».

\section{Процесс, которого не могло не быть}

До недавнего времени историки и юристы, изучая крупные, получавшие мировой резонанс судебные процессы в СССР 1920-1930-х гг., были в известной мере детерминированы в своих подходах и оценках. В советской историографии безоговорочно исповедовалась догма «Краткого курса» о логике «ликвидации эксплуататорских классов» с их все более опасными формами классовой борьбы и будто бы разветвленным подпольем. Новейшая постсоветская историческая традиция сформировала свою парадигму исследования и оценок: подчеркивается, что практически все показательные судебные процессы не имели под собой не только достаточной, но вообще никакой правовой основы и носили фальсифицированный характер, где «царицей доказательств» выступало собственное признание в совершенных «преступлениях», о чем открыто говорили в своих выступлениях и Н. Крыленко (государственный обвинитель), и А. Вышинский (председатель суда) [цит. по: Судебный процесс «Промпартии», 2017. С. 729].

Что же ищут современные исследователи в этих судебных постановочных действиях, коль скоро для многих историков и публицистов «и так все ясно!»? Очевидно, что необходимо рассмотреть эти события не только в аспекте изучения технологий фальсификаций (чекистских, судебных, пропагандистских), но и того, каковы глубинные причины перерастания достаточно банального «дела», каких были сотни, в масштабный процесс; каково было целеполагание того или иного процесса и в какой мере их явные или скрытые цели оказались достижимыми; насколько инициаторам процессов удалось избежать негативных последствий, вызванных «инсценированными» публичными судами? Данная публикация содержит авторское видение ответов на поставленные вопросы и основана на изучении следственных материалов по «Шахтинскому делу», неопубликованных стенограмм процесса и делопроизводства Политбюро ЦК ВКП(б) (более двухсот единиц хранения).

Начнем с причин «Шахтинского дела», первого в ряду «Больших вредительских процессов»: далее последовали процессы «Промпартии» (1930) и «меньшевистский» (1931). Все советские, да и значительная часть современных историков, рассматривают «Шахтинское дело» в системе либо политических координат (инструмент внутриэлитной борьбы и начало наступления Сталина на «правых»), либо социальных (смена партийного курса в отношениях власти и «старых спецов»), либо экономических (углубление экономических противоречий и кризис нэпа, для которых требовалось отыскать виновных). Можно сказать, что весной 1928 г. все три причины сошлись в одной точке, а «спецы» оказались так называемой группой риска.

На укрепление этой позиции должен, казалось бы, работать и тот факт, что в это время возникла мощнейшая конфликтная ситуация по линии «город - деревня», обозначенная в советской литературе как «кулацкая хлебная стачка», а позднее - «кризис хлебозаготовок». На состоявшемся в апреле 1928 г. Объединенном Пленуме ЦК и ЦКК ВКП(б) ключевыми вопросами были названы причины хлебозаготовительного кризиса и уроки, извлеченные из него, и «Шахтинское дело» в той же постановке. Агитпроп, развернувший после Пленума обе кампании, упирал на редуцированное объяснение причин: в первом случае - «кулак регульнул», во втором - «регульнул спец-вредитель». Хотя, как самокритично считал Н.И. Бухарин, «мы сами себя регульнули» [Бухарин, 1990. С. 273].

Но если принять на веру обе причины, то возникает вполне резонный вопрос об «уроках» и мерах, предпринятых властью в ответ на эти «контрреволюционные угрозы». «Размычка» с деревней, которая была куда масштабнее и опаснее вредительства «спецов» в отдельном угольном тресте, имела ответом развертывание в феврале-мае 1928 г. репрессивных акций по привлечению к судебной ответственности «злостных держателей хлеба» (ст. 107 УК РСФСР). По предложению Сталина под эту статью, 
ранее нацеленную против спекулянтов и перекупщиков зерна, «подвели» его прямых производителей - крестьянские хозяйства. Суды, носившие демонстрационный, показательный характер, все же проходили на уровне районного центра и имели прагматичную цель - «подхлестнуть» хлебозаготовки. Затем, чтобы умиротворить всколыхнувшееся крестьянство перед началом полевых работ, кампанию свернули, низовых работников обвинили в «перегибах», часть из них осудили на реальные сроки.

Уроки «Шахтинского дела» привели к иной, куда более мощной и значимой для власти мобилизационно-пропагандистской кампании, кульминацией которой стал громкий процесс 18 мая 6 июля 1928 г. над «спецами-вредителями». В целом же, с периода следствия и послепроцессной пропаганды, «шахтинская» кампания продолжалась с марта и до конца 1928 г. и не сводилась лишь только к судебному процессу, обозначив целый спектр насущных задач: ускорение подготовки «новых кадров красных специалистов»; усиление выдвижения рабочих на административные должности; более широкое вовлечение масс в работу производственных совещаний, контрольных комиссий; устранение недостатков в работе на производстве так называемых треугольников (руководителей хозяйственных, профсоюзных и парторганизаций $)^{1}$.

\section{7-й год:}

\section{кризис большевистской легитимности?}

Как видим, «Шахтинское дело» не сводилось только к «искоренению вредительства», а являлось лишь своего рода ярким, публичным действием в ряду «хозяйственно-политических» кампаний 1928 г. Чтобы понять его более глубинные причины и основания, обратимся к событиям 1927 г. Их социально-политическая динамика определялась двумя факторами: «военная тревога» и десятилетняя годовщина Октября. Под «военной тревогой» подразумевались конфликты и проблемы в сфере межгосударственных отношений (разрыв дипломатических отношений с Англией; убийство полпреда П. Войкова в Варшаве; подавление попытки рабочего мятежа в Китае). Развернувшаяся

' КПСС в резолюциях и решениях съездов, конференций и пленумов ЦК. Ч. ІІ. 1925-1953. M., 1953. 1024 c. [385-390] пропагандистская кампания сплочения народа перед лицом угрозы интервенции привела к неожиданным для власти результатам. Обладавшее горьким опытом выживания в экстремальных условиях население лихорадочно запасалось всем необходимым, создав коллапс на потребительском рынке. Но для власти оказалась важна не столько поведенческая паника, которая через несколько месяцев несколько улеглась, хотя в сознании обывателей «осадок остался»), сколько обнаружившееся во многих слоях населения отсутствие желания «брать винтовку». Безусловно, социологического мониторинга с выявлением доминировавших настроений с их долевыми распределениями проводиться не могло. Однако выявилась очевидная поляризация мнений, причем массовыми оказались условно «оборонческие» и даже «пораженческие» настроения. Это стало сигналом об отсутствии безоговорочной поддержки власти населением в случае военной интервенции.

Власть не мог не беспокоить и обострившийся «рабочий вопрос». Рассматривая ситуацию в сфере труда ретроспективно, за несколько предыдущих лет, нельзя не отметить, что в годы нэпа постоянно нарастала, а затем приобрела устойчивый характер напряженность в производственных коллективах, выразившаяся в стихийных, а затем и организованных волнениях (забастовках). Недовольство и протестные настроения охватывали все категории рабочих (от кадровых до малоквалифицированных); в забастовках участвовали даже члены партии и комсомольцы, а также профсоюзные низовые работники. Между тем для внутренней политики большевиков абсолютным приоритетом, предметом особой озабоченности были взаимоотношения власти с рабочими, в доктринальном смысле объявленными не просто «передовым классом», но и символом нового режима.

Если отвлечься от идеологическо-пропагандистских постулатов, формировавших в лице рабочих «правильную» (нормативную) политическую и социокультурную идентификацию, на которую призваны были равняться другие страты, и погрузиться в реалии социально-трудовых отношений на производстве, то именно здесь возникали, накапливались и вспыхивали всевозможные конфликты и нестыковки, создававшие почву для, пользуясь терминологией эпохи, «размычки» между рабочими и властью. 
Рабочим позволялось многое из того, что было недоступно другим, «непролетарским» слоям и профессиям: преференции в образовательной сфере (рабфаки), в номенклатурном продвижении (выдвиженчество), при приеме в партию и любые общественные организации; рабочий статус давал определенные преимущества в суде (мягкость приговоров) и при исполнении наказания и т.д.

Однако за все это рабочим требовалось платить достаточно высокую социально-политическую цену в виде не просто выражения лояльности режиму, но активной и безоговорочной его поддержки. Рабочие являлись средой приоритетного социальнопрофессионального пополнения партийных и комсомольских рядов. Рабочие-партийцы, остававшиеся на производстве, обязывались в порядке партийной дисциплины поддерживать все, в том числе и самые непопулярные решения администрации, часто шедшие вразрез с насущными интересами рабочей массы. Своего рода «заложничество» рабочих-активистов создавало и усиливало двойственность их положения в трудовых коллективах.

В самой партии, начиная с середины 1920-х гг., динамика приливов (приема в партию) и отливов (выбытия по тем или иным причинам) становилась тревожной. В 1926 и 1927 гг. число вступавших в партию сокращалось, а выходы из нее увеличивались. На металлургическом комбинате «Югосталь» (Украина) из парторганизации численностью 1500 чел. летом 1927 г. вышла пятая часть ее состава, но и на оставшихся нельзя было положиться. В 1928 г. в 7,4\% случаев организаторами забастовок выступали члены партии и комсомольцы [Великанова, 2017. С. 22, 117]. На производстве накапливался немалый потенциал «бывших», покинувших партию по разным причинам, но сохранявших свой активизм, проявлявшийся во время трудовых конфликтов.

Трудовые отношения на производстве оказывались главным полем, где нарастала социальная напряженность и напрямую сталкивались интересы различных групп рабочих и рабочих коллективов в целом и интересы государства «пролетарской диктатуры». Так называемые треугольники, призванные обеспечить баланс интересов управляемых и управленцев (профсоюзов, партийных организаций и хозяйственников), плохо справлялись с этой задачей. Вследствие хронических сбоев на производстве и периодически проводившихся кампаний по рационализации (как правило, сопровождавшихся пересмотром норм выработки и снижением расценок) деятельность этих треугольников воспринималась рабочими как наступление на их трудовые права всей управленческой вертикали с падением авторитетности власти, справедливо ассоциирующейся с партией. Приведенные в диаграммах динамика и структура забастовок в стране во второй половине 1920-х гг. отчетливо показывают рост рабочего протеста к 1928 г. и определенный спад после, что является сюжетом отдельного аналитического разбора (рис. 1,2 ).

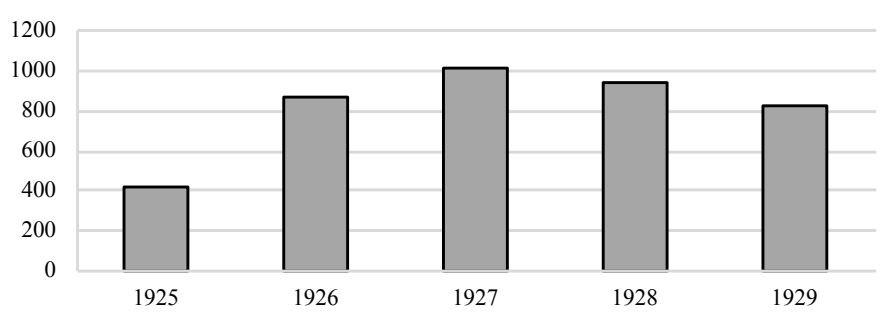

Рис. 1. Количество забастовок в России в 1925-1929 гг.

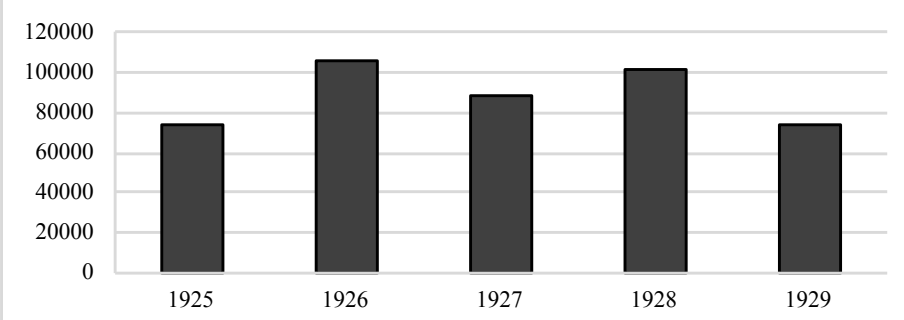

Рис. 2. Число участников забастовок в России в 1925-1929 гг., чел.

Здесь же отметим лишь, что экономический протест рабочих, становившийся устойчивым «раздражителем» для власти, покуда он не начал перерастать в более опасные формы, следовало перевести в иное русло, придав ему социально-политический характер. В этом смысле как нельзя более на руку власти оказалось распространение в широких рабочих массах так называемых антиспецовских настроений, или «спецеедство».

«Болышой» показательный судебный процесс над «спецами-вредителями» был жизненно необходим для власти весной 
1928 г., чтобы решить задачу восстановления распадающейся «смычки» с рабочей массой. Будучи по форме судом над группой управленческо-технической интеллигенции Донбасса, Шахтинский процесс содержательно имел куда более глубокие социально-политические причины и мотивы. Он был «поставлен» большевистским руководством ради и для рабочей среды, а «спецы» являлись объектом общей социальной неприязни, сближавшей тех и других.

\section{«Вредительство» как угроза,}

\section{«спецеедство» как реальность}

Как и большинство социальных фобий, интеллигентофобия (и-фобия) (авторский термин - C. K.) имела свои прочные корни и основания еще в позднеимперском обществе. Согласно данной точке зрения, интеллигенция, участвуя в рабочем движении, являлась не союзником, а потенциальным противником пролетариата, на плечах которого в ходе социальной революции она придет к власти в качестве нового эксплуататорского класса. На уровне цивилизационном речь шла, безусловно, о конфликтах между работниками умственного и физического труда. В России и-фобия проявляла себя в эксцессах на производстве, когда инженеры, имевшие высокий социальный статус и включенные в систему управления производством, естественно, ассоциировались в сознании рабочих с «эксплуататорами».

Послереволюционная и-фобия, обозначенная новоязом как «спецеедство», произрастала и воспроизводилась во многом на прежней основе, базируясь на социально-культурных антагонизмах, обострившихся в революционную эпоху. Положение интеллигенции в постреволюционном обществе осложнялось инерционностью социально-экономических отношений в производственной сфере. Несмотря на радикальные политические сдвиги, ролевые функции рабочих и специалистов оставались здесь прежними - на большинстве предприятий сохранялись и воспроизводились иерархические отношения между управленцами и рабочими. Возникало очевидное противоречие между декларированными политическими преференциями в пользу рабочих и их реальным статусом наемных работников, находившихся в зависимом положении от «буржуазных спецов», которые к тому же имели, очевидно, более высокий уровень жизни (в 1925 г. средняя зарплата высококвалифицированных специалистов в металлургии в 5-6 раз превосходила зарплату квалифицированного рабочего и в 10 раз - чернорабочего) [Федюкин, 1972. С. 296]. Взятый руководством страны курс на форсированную индустриализацию, требовавший социальных жертв и издержек, в том числе от рабочего класса, только усилил социальную напряженность, и, соответственно, «спецеедство» «снизу».

«Спецеедство» «сверху» также имело свои причины и динамику. Если ядро новой правящей бюрократии составили вчерашние политические маргиналы, большинство из которых были выходцами из радикальной интеллигенции, то основная масса советских управленцев рекрутировалась из социальных слоев с невысоким культурным уровнем. Будучи маргинальной по источникам своего пополнения и социокультурным характеристикам, формирующаяся советская номенклатура не могла не прибегнуть к социально-политической мимикрии, встраиваясь в собирательную категорию «служащие», внутри которой советские переписи выделяли их в качестве особой группы «руководящий персонал». Среди последних, составлявших по переписи 1926 г. 328 тыс. чел., половина была представлена лицами в возрасте до 30 лет $^{2}$. Не обладая достаточным опытом для принятия и реализации управленческих решений, новая номенклатура не могла обойтись без специалистов, составлявших управленческую «периферию», но именно их необходимость формировала к ним корпоративную неприязнь со стороны новой элиты. В кризисных ситуациях, наиболее крупной из которых после окончания Гражданской войны стал системный кризис 1927-1928 гг., бюрократия без сожаления жертвовала частью своей «периферии», переводя массовое социальное недовольство «низов» в русло и-фобии.

\section{«Рабочая линия» в «Шахтинском деле»}

Установив, что в процессе против «вредителей» большевистское руководство сознательно и акцентированно использовало негативизм рабочих в отношении производственно-технической интеллигенции, покажем далее, какая роль отводилась рабочим

${ }^{2}$ Изменения социальной структуры советского общества (1921 - середина 1930-х годов). М.: Мысль, 1979. 343 с. [С. 168, 169] 
на стадии «вскрытия» «вредительства» в Шахтинском рудоуправлении. Впоследствии сами чекисты признавали, что мотивом к следственным действиям в отношении специалистов выступали систематические жалобы рабочих о допущенных нарушениях на производстве (не выходивших, впрочем, за пределы рутинных экономических претензий: низкие расценки, несвоевременные выплаты заработной платы, обсчеты и т.д.).

Ситуация стала резко меняться летом - осенью 1927 г., после того как чекисты начали искать в такого рода «сигналах» политическую составляющую, которую можно было определить как «вредительство». На этой стадии следствия, которое велось силами сотрудников Шахтинского оперсектора с брошенной к ним на усиление группой сотрудников Экономического управления (ЭКУ) Ростовского ОГПУ, «рабочая линия» эксплуатировалась путем давления на арестованных посредством показаний рабочих и очных ставок с ними. Так, в следственном деле управляющего одной из шахт Н. А. Гавришенко (671 лист; арестован в июне 1927 г., покончил с собой 30 января 1928 г., выбросившись во время допроса из окна здания ОГПУ в Ростове-на-Дону) сохранились более ранние (апрель 1927 г.) заявления от ряда рабочих о невыплате им причитающихся премий. Есть документированные данные об интенсивности следственных действий (список 72 опрошенных свидетелей, протоколы 20 очных ставок с рабочими, дававшими против него показания) [Шахтинский процесс... Кн. 2, 2011. С. 1004].

Помимо производственной сферы, чекисты пошли по пути активной проработки прошлой деятельности и поведения специалистов, особенно в период революции и Гражданской войны. Политический компромат оказался результативнее производственного. В этом пространстве чекистам куда легче было выдвигать обвинения и давать оценки действиям арестованных, а последним труднее было оправдываться. В ход шли показания как рабочих, так и бывших агентов белых спецслужб³.

Другие важные и весьма символичные жесты в сторону рабочих совершались уже в ходе судебных заседаний. Так, в состав суда, помимо профессиональных юристов (А. Я. Вышинский, В.П. Антонов-Саратовский и М.И. Васильев-Южин), были

${ }_{3}^{3}$ Центральный архив ФСБ РФ. Ф. Р-49447. Т. 42. Л. 91-91 об. включены рабочий Н. Курченко из Горловки (крепильщик, член партии, профсоюзный активист) и С.А. Киселев от рабочих Москвы. Данное обстоятельство призвано было зафиксировать особую роль рабочих как активных участников процесса. Среди тщательно отобранных свидетелей, выступавших в судебных слушаниях, преобладающей была доля рабочих. По квотам на получение удостоверений для присутствия на суде (с периодической сменой состава аудитории) приоритет также отдавался рабочим, а за формирование списков от предприятий не только Москвы, но и других рабочих центров отвечал ВЦСПС.

Наиболее агрессивно и разнопланово «рабочая линия» проявила себя в ходе агитационно-пропагандистской кампании, развернутой вокруг «Шахтинского дела». Газетно-журнальные полосы в предпроцессный период, а также во время самого суда наполнялись публикациями и материалами о реакции рабочих коллективов на «вскрытую экономическую контрреволюцию в Донбассе» с требованиями «суровой расправы» над «вредителями». Если рассматривать результативность развязанной кампании с точки зрения воздействия на основную целевую аудиторию в лице рабочих, то нет сомнений в том, что ее главная задача оказалась реализованной: социальное недовольство рабочих было перенаправлено в нужное для власти русло, на «спецоввредителей».

В качестве примера приведем сведения о настроениях рабочих-горняков в Луганском округе Донбасса накануне и по итогам Шахтинского процесса (из годовой сводки окротдела ГПУ за 1928 г.): «Аресты среди технического персонала всколыхнули рабочих; особенно это понятно в условиях горной промышленности, где между рабочими и техническим персоналом на почве разительной разницы в условиях быта существует легко прощупываемый антагонизм. Условия быта горняка при наличии скверных жилищных условий, тяжелых форм работы, неполадок в производстве - создают вполне естественную некоторую озлобленность рабочего, вылившуюся ... при раскрытии “Шахтинского дела" в резко выраженную неприязнь и злобу по отношению к техническому персоналу. "Давно пора взяться за техников и инженеров. За последнее время они так обнаглели, что рабочим жить нельзя", - такое мнение являлось преобладающим среди большинства рабочих и высказывалось на всех происходящих 
рабочих собраниях. Твердо укрепилось мнение, что ВЕСЬ ТЕХНИЧЕСКИЙ ПЕРСОНАЛ НАСТРОЕН КОНТРРЕВОЛЮЦИОН-

НО (выделено в источнике - C. K.). Настроения эти имели место среди рабочих в течение продолжительного времени, причем угрожали перейти в открытую форму спецеедства. [...]

Как следствие отмеченных настроений, рабочие ожидали сурового приговора со стороны суда по отношению Шахтинских вредителей. Решение суда не удовлетворило рабочих, которые считали, что Советская власть слишком мягко отнеслась к вредителям. Большинство мнений сводилось к тому, что $2 / 3$ вредителей надо расстрелять и тогда это явилось бы хорошим уроком для всех остальных» [Шахтинский процесс... Кн. 2, 2011. C. 985-986].

\section{Для «сцены” должен быть “сценарий». Следствие и 53 подсудимых}

Поскольку данный открытый процесс имел целеполагание как постановочное действие, в котором всем участникам отводились предписанные роли, следует задаться вопросом - насколько удачным был сам «сценарий» и успешной «постановка». Рассмотрим, в каких компонентах процесс, с точки зрения его создателей, достиг предписанных результатов, а в чем итоги не совпали с ожиданиями.

«Сценарий» того, что в угольной промышленности Донбасса сложилась разветвленная «вредительская организация из числа старых спецов, связанных со своими прежними дореволюционными шахтовладельцами и получавшими на вредительскую деятельность средства от них, а также ряда зарубежных правительственных структур», первоначально принадлежал полпреду ОГПУ по Северному Кавказу Е.Г. Евдокимову. После того как ему удалось убедить Сталина в наличии такой организации, следствие распространилось на украинскую территорию Донецкого бассейна, где арестами и дознанием в Харькове (в правлении треста «Донуголь») занимались украинские чекисты. На завершающей стадии аресты «московского Центра» производились уже чекистами из центрального аппарата ЭКУ ОГПУ.

Первые девять человек были арестованы еще летом-осенью 1927 г., и затем шахтинско-ростовский этап следствия забуксовал: «признательные показания» удалось получить лишь у отдельных арестованных только в январе-феврале 1928 г. Причем ключевую роль сыграли «показания» зав. шахтой Н.А. Гавришенко и техника А.Б. Башкина, которые в результате массированных допросов находились уже в пограничном состоянии. Гавришенко еще до самоубийства предпринимал попытку суицида в тюрьме, а последний прижизненный протокол его «показаний» содержал взаимоисключающие ответы на задаваемые вопросы. Башкин еще до своего ареста находился несколько лет под наблюдением врача-психиатра, а после интенсивных допросов (с 21 января по 23 марта он допрашивался 48 раз) был отправлен в клинику на лечение, после чего допросы возобновились. «Ценность» Башкина для следствия состояла в том, что он имел переписку с братом-эмигрантом, проживавшим в Германии, и периодически получал от него небольшие посылки с одеждой и предметами «ширпотреба». В итоге Башкин дал «показания» о том, что через него осуществлялась «связь с заграницей».

Из сказанного становится понятным, почему первоначально собранная ростовскими чекистами «доказательная база» не встретила поддержки ни у Г.И. Ломова (пред. правления треста «Донуголь», известного большевика), ни у В.Р. Менжинского (пред. ОГПУ) и А.И. Рыкова (пред. СНК СССР). Затем число скептиков пополнил В.В. Куйбышев (пред. ВСНХ СССР), считавший, что следствие надо осторожно продолжать, не заявлять о «раскрытии вредительской организации» и готовить открытый процесс. Да и позднее, когда политическое решение о подготовке процесса с санкции Сталина было публично оглашено в печати (10 марта в газете «Правда»), синдром того, что «Шахтинское дело» имело своим спусковым механизмом показания двух очевидно нездоровых людей, продолжал проявлять себя в руководящих кругах страны.

В частности, становятся понятными фразы из обмена записками 29 марта 1928 г. между К.Е. Ворошиловым и М.П. Томским, вернувшимся после двухнедельной поездки по Донбассу. Ворошилов: «Миша, скажи откровенно, не вляпаемся мы при открытом суде в шахтинском деле? Нет ли перегиба в этом деле местных работников, в частности краевого ОГПУ?». Томский: «По шахтинскому и вообще по угольному делу такой опасности 
нет, ибо картина ясная. Главные персонажи в сознании» (подчеркнуто в тексте М. Томским - C. K. $)^{4}$.

Второй этап массовых арестов по «Шахтинскому делу» совпал с политическим решением о процессе, принимавшимся в недрах Политбюро. Тогда харьковские чекисты с 3 по 10 марта 1928 г. взяли под стражу 19 работников центрального аппарата треста «Донуголь», из числа которых по преимуществу и был «сконструирован» «харьковский Центр», до 15 апреля 1928 г. в тюрьме оказалось еще 20 чел. (на базе этих арестов создавались «московский Центр» и своего рода «периферия» заговора).

Три волны арестов специалистов дали в совокупности 53 подсудимых для процесса в Колонном зале Дома союзов, хотя арестная кампания только в аппарате и рудоуправлениях треста «Донуголь» затронула 160 чел. из почти 200 «старых инженеров». Аресты, проводившиеся ростовскими, украинскими и московскими чекистами, которые часто руководствовались корпоративными интересами, привели в итоге на скамью подсудимых крайне пеструю группу «вредителей». Это сказалось как на качестве предварительного следствия, так и на поведении подсудимых в ходе процесса, который с позиций строго юридических норм и процессуальной судебной практики был крайне уязвим. Еще более абсурдистской эту картину делал «немецкий след», представленный тремя подданными Германии, работавшими по контрактам в СССР и арестованными также за «вредительство».

Интенсивность чекистского дознания, нараставшая по мере приближения даты процесса, приходила в очевидное противоречие с достигнутыми результатами. Из 53 подсудимых к началу процесса полностью виновными в предъявленных им обвинениях признали себя 20 чел., 10 чел. вину признали «частично» и 23 чел. отрицали выдвинутые против них обвинения. Такого рода позиционного размежевания среди подсудимых не было ни до, ни после Шахтинского процесса.

Если рассматривать динамику соотношения этих групп внутри трех «арестных волн», увидим, что в первой из них (шахтинскоростовской) доля признавшихся составляла $50 \%$, а «отказчиков»$35 \%$, во второй волне (харьковской) доли этих групп были равны

${ }^{4}$ Как ломали нэп. Стенограммы пленумов ЦК ВКП (б) 1928-1929 гг.: в 5 т. Т. 1. М. МФД, 2000. 495 c.[С. 30]. (по 40\%), а в третьей (условно московской) - доля признавшихся (25\%) была вдвое меньше «отказчиков» (50\%). Впрочем, для государственного обвинителя Н.В. Крыленко такое количество «нераскаявшихся» лишь послужило поводом для обоснования тезиса о многоликом и укоренившемся «вредительстве», противопоставления этих групп друг другу и поддерживания иллюзии борьбы на процессе (в 1930 г. в ходе суда над членами мифической «Промпартии» он выскажет сожаление об исчезновении подобной «интриги»). Следует отметить, что в просмотренном нами следственном делопроизводстве по Шахтинскому процессу (почти полторы сотни дел) не оказалось ни одного вещественного доказательства связей арестованных с заграничными предпринимателями или посольствами и фирмами, документов «организации» (переписка, наличие крупных сумм, изъятых при арестах и т.д.).

Однако в 1928 г. Крыленко не просто давал высокую оценку чекистскому дознанию, но и полагал, что признательные показания арестованных являются весомым подтверждением их вины, отбрасывая фактор безусловно имевших место самооговоров и оговоров одних другими.

\section{Цена «признательных показаний»}

Протоколы следствия по «Шахтинскому делу», как правило, не дают возможности зафиксировать те «доверительные» соглашения обвиняемых со следствием, которые обеспечивали чекистам нужные для них показания. Более достоверны протоколы допросов тех, кто противостоял следствию либо аргументированно доказывал свою невиновность, отказываясь отвечать на вопросы. В таких случаях следователи обычно сворачивали допросы, понимая, что на то, чтобы сломать этих людей, могут потребоваться недели или месяцы, в то время как сроки поджимали, а число сотрудничавших со следствием считалось вполне достаточным (20 чел. из 53 обвиняемых).

Тем более ценным оказалось письмо, найденное в личном фонде знаменитого адвоката Н.К. Муравьева, считавшегося одним из лучших защитников на еще дореволюционных политических процессах. За неделю до Шахтинского процесса он встретился в Бутырской тюрьме с Ю.Н. Матовым и С.П. Братановским, которые оказались в числе основных обвиняемых, 
поскольку занимали до ареста ключевые должности в тресте «Донуголь». Оба признали себя в ходе следствия виновными.

Уже при первой встрече Н.К. Муравьева «поразило их крайне легкомысленное отношение к своему положению»: будучи обвиненными сразу по двум статьям (58-3 «контакты с иностранным государством в контрреволюционных целях» и 58-7 «вредительство», что в совокупности грозило смертной казнью- C. К.), «на мой вопрос, какого результата процесса они ждут для себя, один из обвиняемых (Матов) ответил, что ему, вероятно, придется посидеть несколько месяцев, прежде чем вернется «на производство». Приблизительно в том же роде были предположения и другого обвиняемого. [...] Но со второго или третьего свидания они оба, весьма взволнованные, в особенности Матов, открылись мне, что их показания на дознании, подтвержденные - без опроса их по существу - следователю, не соответствуют действительности, что они их дали сперва вследствие того тяжелого морального и физического состояния, в котором они находились, а потом - вследствие того, что они пришли к убеждению, что так именно нужно, чтобы они показывали, что этого от них требуют и ждут люди, которые лучше их знают, что нужно, и что в случае исполнения этого требования и удовлетворения этого ожидания они могут быть спокойны за свою судьбу и скоро будут возвращены на “производство”. Они подробно рассказывали, как они сперва относились равнодушно к тому, что подписывали, а потом стремились пойти навстречу следователям, выведать от следователей то, что показывали другие обвиняемые... стремились давать детали, лишь бы быть отнесенными “к первой категории” по легкости наказания, то есть к тем лицам, которых ждет возвращение на производство».

Поняв, что происходило в ходе следствия с обвиняемыми, Н.К. Муравьев решил выяснить у других защитников, были ли самооговоры и оговоры сделаны другими заключенными. «Сведения были единодушны. Почти все сознавшиеся обвиняемые признались своим защитникам, что они ложно оговорили себя и других; что почти все они боятся сказать правду, так как опасаются, что этой правде суд не поверит; что один из обвиняемых, не признавший себя виновным, добивался у защитника ответа, не нужно ли ему оговорить себя и других, чтобы получить снисхождение, как другие» ${ }^{5}$. В связи с этим Н.К. Муравьев принял тяжелое решение - отказаться от участия в защите Матова и Братановского, о чем и написал в объяснительном письме на имя председателя президиума Московской коллегии защитников В.Ф. Белякова, благодаря этому в распоряжении у историков оказалось уникальное по своей значимости документальное свидетельство тотальной фальсифицированности чекистского следствия по «Шахтинскому делу».

\section{Приговор подсудимым: что оказалось не так}

Формула приговора для знаковых судебных процессов политического характера в СССР определялась отнюдь не в совещательной комнате Верховного суда, а в обстановке сверхсекретности на самом «высшем уровне». Для надзора и контроля за «правильным» развитием событий была создана комиссия по «Шахтинскому делу» под председательством А.И. Рыкова, включавшая ряд членов Политбюро с привлечением «профильных» наркомов. Функционально комиссия занималась синхронизацией действий различных ведомств, вовлеченных в обеспечение процесса (ОГПУ, Наркомюст, НКИД и др.). Она же контролировала ход и направления агитационно-пропагандистской кампании и санкционировала текст обвинительного заключения. На основании сохранившихся документов комиссии и ее переписки с Политбюро можно с точностью утверждать, что еще до завершения процесса дипломаты в лице Г.В. Чичерина и Н.Н. Крестинского обосновали необходимость оправдательного приговора в отношении трех немецких подданных, привлеченных к суду, что в итоге и произошло. Один из них, В. Бадштибер, был осужден условно сроком на 1 год, но смог уехать на родину сразу после суда.

Ключевым был вопрос, как его мрачно окрестил один из защитников М.А. Оцеп, «о головах». Н.К. Муравьев еще до суда подметил, что из общего числа подсудимых по формальным основаниям выделялась группа из десяти человек, обвиняемых по «расстрельным статьям». Государственный обвинитель Крыленко требовал больше «голов», но решением суда к смертной казни суд приговорил 11 чел. Далее 8 июля Президиум ЦИК 
СССР в отношении шестерых осужденных эту меру заменил 10 годами лишения свободы. Согласно сообщению газеты «Правда», 9 июля пятеро осужденных были расстреляны ${ }^{6}$.

Из документов Политбюро следует, что вопрос «о головах» был предметом обсуждения на расширенном заседании Политбюро с участием членов ЦК и ЦКК ВКП(б) 3 июля 1928 г. К сожалению, резолюции в архиве Политбюро мы не обнаружили (такое крайне редко, но случалось, когда решение принималось, но не документировалось). Впрочем, историки могут опираться в этом вопросе на свидетельство одного из ключевых участников данного события, Н.И. Бухарина, который 11 июля в ходе встречи с опальным Л.Б. Каменевым обмолвился о поразившем всех «правых» поведении Сталина на этом заседании: «Он предлагал ни одного расстрела по Шахтинскому делу (мы голоснули против)...» ${ }^{7}$.

Между тем официальная информация в печати о том, что 9 июля 1928 г. «приговор в отношении осужденных к расстрелу Горлецкого, Кржижановского, Юсевича, Будного и Бояринова приведен в исполнение» ${ }^{8}$, оказалась не вполне достоверной. В ходе исследования другого крупного «вредительского» процесса над так называемой Промпартией (1930 г.) удалось выяснить, что Н.К. Кржижановский и Н.А. Бояринов смертной казни избежали.

Осенью 1931 г. Президиум ВСНХ СССР направил в Комиссию по частной амнистии (Комча) при ЦИК СССР ходатайство «об освобождении или изменении меры социальной защиты в отношении 21 осужденного Верхсудом специалиста». Экономическое управление ОГПУ поддержало это предложение, сочтя «возможным применить к последним амнистию, с использованием их по специальности в промышленности» ${ }^{9}$. В приложенном списке специалистов под № 3 значился Николай Константинович Кржижановский с пометкой: для его использования на Урале, в Соликамске, калийном объединении, а под № 10 - Николай Антонович Бояринов для его использования

\footnotetext{
${ }^{6}$ Правда. 1928. 11 июля.

Социалистический вестник, Берлин. 1929. 22 марта.

8 Правда. 1928. 11 июля.
}

${ }^{9}$ ГА РФ. Ф. Р-3316. Оп. 64. Д. 1205. Л. 3. в тресте «Средазуголь» ${ }^{10}$. Следует констатировать, что это, вероятно, единственный в истории советских судебных политических процессов случай, когда объявленный в печати исполненным смертный приговор в отношении двух «смертников» не состоялся. Тем самым необходимо внести соответствующие коррективы во все справочные издания, энциклопедические, прежде всего, где говорится о пяти расстрелянных «шахтинцах».

\section{Итоги процесса: что оказалось не так}

Необходимо иметь в виду, что полуторамесячный судебный процесс являлся лишь «надводной частью» громадного и многоаспектного социального, политического, экономического и культурного «айсберга» под названием «Шахтинское дело», которое длилось не менее года. Если рассматривать его результаты и последствия (текущие и долговременные) в соотнесении с целями, которые ставило перед собой высшее руководство страны, то они оказались в одних случаях реализованными, а в других - послужили источниками новых кризисов и негативных явлений. Главная целевая установка, как уже отмечалось, оказалась реализованной - негативизм рабочих в отношении партии и партийного государства удалось перенацелить на «спецоввредителей», сыграв на массовых антагонизмах между рабочими и производственной интеллигенцией.

Другая же задача, возможно, даже более значимая для укрепления власти - направить рабочий активизм в позитивное русло развития экономики (участие в массовых производственных организациях и движениях в целях рационализации, роста производительности труда; вовлечение в низовые управленческие структуры (выдвиженчество) и т.д.) оказалась в большей степени нереализованной. И здесь, помимо главной, глубинной причины (недостаточный социокультурный и профессиональный уровень основной массы рабочих), свою дестабилизирующую роль сыграло разрушение в ходе борьбы против «вредительства» тонкой ткани социально-трудовых отношений. Распространение «спецеедства», падение трудовой дисциплины негативно сказались на производственных показателях, прежде всего,

${ }^{10}$ ГА РФ. Ф. Р-3316. Оп. 64. Д. 1205. Л. 4. 
в горнодобывающей промышленности, а также в других секторах экономики. Специалисты, дезорганизованные не столько репрессиями, сколько угрозой их применения и атмосферой недоверия и негативизма со стороны рабочей массы, стремились покинуть «опасное» производство, переходя в управленческие структуры.

На совещании Политбюро в конце 1928 г. по ситуации в Донбассе (ощутимое снижение угледобычи вместо ожидавшегося роста) многое из порожденного «Шахтинским делом» негативизма на производстве озвучил руководитель треста «Донуголь» Г.И. Ломов, его дополнили фактами другие выступавшие. Все они были единодушны в том, что «Шахтинское дело» стало первопричиной проявившегося с весны 1928 г. системного «сбоя» на производстве, поскольку на этой основе резко выросла напряженность и участились конфликты в сфере социально-трудовых отношений, произошло нарастание «спецеедства». Ломов привел, в частности, сведения ГПУ Артемовского округа о том, что только за ноябрь 1928 г. по округу было зафиксировано «28 случаев резких эксцессов против технического персонала» ${ }^{11}$.

Фактически многие казавшиеся правильными расчеты оборачивались в итоге просчетами и ошибками, поскольку директивное воплощение их в практику вело к противоположным результатам. Изъятие путем репрессий «спецов-вредителей» и замена их выдвиженцами из среды рабочих привели к дезорганизации производства. Г.И. Ломов признавал, что замена руководящего состава «чрезвычайно часта и вредно отражается на производстве». На рудниках Шахтинского района в течение трех месяцев с начала кампании административно-технический персонал всех уровней обновился на 80\%: «часть [...] выбыла вследствие ареста, часть в порядке устранения с работы после ареста, несмотря на освобождение, часть в порядке замещения вновь выдвинутыми работниками» ${ }^{12}$.

Принципиальное значение имело выступление на совещании И.В. Сталина, давшего свое видение «уроков шахтинского дела»: «Конечно, результаты шахтинского процесса не могли не нанести удар по хозяйственникам в смысле замены старых спецов новыми. Спецы нужны. Ясно, что одни коммунисты не могут управлять Донбассом... Шахтинский процесс, кроме того, что он внес очищающую атмосферу в Донбасс, вместе с тем имел и свои минусы. ....Мы должны знать, что ежели спецы предавали, а рабочие это чутьем видели, а мы молчали, это не могло не отразиться на усилении недоверия рабочих к власти. Это безусловно. Если этот минус вычеркнуть, то общий баланс от шахтинского процесса, безусловно, положительный» ${ }^{13}$.

Логика сталинских оценок итогов, уроков и последствий Шахтинского процесса имела под собой вполне очевидные политические основания. Именно в этом контексте - с точки зрения интересов и приоритетов власти - и был выполнен сталинский анализ, и именно как политик он усматривал главный минус в падении авторитета власти в рабочей среде. Однако и положительный баланс от процесса, о котором сказал Сталин на совещании, оказался не очевиден.

Режимом были осознаны и просчеты в организации показательного процесса - слишком большой и разнообразный состав подсудимых, включая иностранных подданных; наличие значительной группы обвиняемых, полностью или частично не признавших свою вину; умелая профессиональная деятельность защиты, вскрывавшей просчеты предварительного и судебного следствия; очевидная декоративность группы рабочих, привлеченных в качестве членов суда, и т.д. Последующие «вредительские» процессы носили уже полностью постановочный, а потому и квазисудебный характер.

\section{Литература}

Бухарин Н. И. Путь к социализму. Избранные произведения. Новосибирск: Наука, 1990. 494 с

Великанова О.В. Разочарованные мечтатели. Советское общество 1920-х гг. М.: РОССПЭН, 2017. 295 c.

Рольф М. Советские массовые праздники. М.: РОССПЭН, 2009. 439 с.

Судебный процесс «Промпартии» 1930 г.: подготовка, проведение, итоги: в 2 кн. Кн.2. М.: РОССПЭН, 2017. 1055 с.

Федюкин С. А. Великий Октябрь и интеллигенция. М.: Наука, 1972. 472 с.

Шахтинский процесс 1928 г.: подготовка, проведение, итоги: в 2 кн. Кн.1. М.: РОССПЭН, 2010. 975 c 
Шахтинский процесс 1928 г.: подготовка, проведение, итоги: в 2 кн. Кн.2. М.: РОССПЭН, 2011. 1087 c.

Статья поступила 04.03.2018.

\section{Summary}

Krasilnikov S. A., Institute of History, SB RAS, Novosibirsk state university, Novosibirsk

Staged by Dictatorship. 90 Years Since the Shakhty Trial, 1928

Historical conceptualizations of one of the biggest Soviet trials (Shakhty, 1928) transitioned from "well founded" to "fabricated", which demands careful rethinking of its reasons, purposes, means and results. Shakhty trial formally was stacked against "specialists-wreckers" but in reality it was a way out of deep systemic crisis: legitimacy decline, growth of negativity towards the government institutions, social unrest. Taking the model of conflict mobilization («us - they») as a basis for show trials, Stalin government not only sacrificed interests and status of the engineers, but also pragmatically used disaffection of the working class with the «delay» of privileges promised for them. Retargeting remonstrative energy of workers towards "spetseyedstvo" (bashing non-party engineers) and encouraging public mood of social revenge of «lower classes» against intelligentsia, the regime evoked new crisis situations (deformation of social and labor relations, extending repressive measures over management and economy).

Legitimacy crisis of the regime; workers' protest; social mobilization; Shakhty trial; «campaign justice»

\section{References}

Bukharin N. I. (1990) Put' k sotsializmu. Izbrannyye proizvedeniya. Novosibirsk, Nauka Publ. 494 p. (In Russ.)

Velikanova O.V. (2017) Razocharovannyye mechtateli. Sovetskoye obshchestvo 1920-kh gg. Moscow, ROSSPEN Publ., 295 p. (In Russ.)

Rol'f M. (2009) Sovetskiye massovyye prazdniki. Moscow, ROSSPEN Publ., 439 p. (In Russ.)

Fedyukin S.A. (1972) Velikiy Oktyabr' i intelligentsiya. Moscow, Nauka Publ., 472 p. (In Russ.)

Shakhtinskiy protsess 1928 g.: podgotovka, provedeniye, itogi (2010). v $2 \mathrm{kn}$. Kn.1. Moscow, ROSSPEN Publ. 975 p. (In Russ.)

Shakhtinskiy protsess 1928 g.: podgotovka, provedeniye, itogi. (2011). v 2 kn. Kn.2. M., ROSSPEN Publ. 1087 p. (In Russ.)

Sudebnyy protsess «Prompartii» 1930 g.: podgotovka, provedeniye, itogi (2017): v 2 kn. Kn.2. Moscow, ROSSPEN Publ., 1055 p. (In Russ.) 